\title{
New insights into the evaluation of broad QRS complexes
}

Citation for published version (APA):

Bogossian, H. (2022). New insights into the evaluation of broad QRS complexes: relevance for arrhythmia management. [Doctoral Thesis, Maastricht University]. ProefschriftMaken.

https://doi.org/10.26481/dis.20220215hb

Document status and date:

Published: 01/01/2022

DOI:

10.26481/dis.20220215hb

Document Version:

Publisher's PDF, also known as Version of record

\section{Please check the document version of this publication:}

- A submitted manuscript is the version of the article upon submission and before peer-review. There can be important differences between the submitted version and the official published version of record.

People interested in the research are advised to contact the author for the final version of the publication, or visit the DOI to the publisher's website.

- The final author version and the galley proof are versions of the publication after peer review.

- The final published version features the final layout of the paper including the volume, issue and page numbers.

Link to publication

\footnotetext{
General rights rights.

- You may freely distribute the URL identifying the publication in the public portal. please follow below link for the End User Agreement:

www.umlib.nl/taverne-license

Take down policy

If you believe that this document breaches copyright please contact us at:

repository@maastrichtuniversity.nl

providing details and we will investigate your claim.
}

Copyright and moral rights for the publications made accessible in the public portal are retained by the authors and/or other copyright owners and it is a condition of accessing publications that users recognise and abide by the legal requirements associated with these

- Users may download and print one copy of any publication from the public portal for the purpose of private study or research.

- You may not further distribute the material or use it for any profit-making activity or commercial gain

If the publication is distributed under the terms of Article $25 \mathrm{fa}$ of the Dutch Copyright Act, indicated by the "Taverne" license above, 


\section{Summary}

Although the ECG has been available for over 100 years, its correct interpretation remains challenging. Physicians continue to find patterns that have not yet been fully explored. Particularly in the presence of broad QRS complexes, interpretation of the ECG is sometimes challenging.

The present thesis analyzes and expands the diagnostic possibilities of the ECG in the presence of broad QRS complexes. It provides information regarding the atrioventricular conduction during bundle branch block (BBB), diagnostic characteristics of different premature ventricular complex (PVC) morphologies and offers a new approach for the correct measurement of the QT interval duration in the presence of BBB.

The measurement of the QT interval in the presence of BBB has traditionally been challenging. Since 2014 we have developed and validated a formula to estimate the anticipated QT interval in the absence of broad QRS (Chapter 2). Subtracting $50 \%$ of the QRS from the measured QT time leads to the modified QT. The formula was extensively validated in patients with intermittent LBBB (Chapter 3), in patients with a pacemaker (Chapter 4), in heart failure patients with an implantable cardioverter defibrillator (Chapter 5) and in patients with right BBB (Chapter 6).

In part 2, we showed that the prolonged HV interval is not associated with the subsequent development of third degree AV block or with increased mortality (Chapter 7). Based on the present evidence, the need for invasive electrophysiological studies might be overestimated in the current guidelines. The decision for pacemaker implantation should therefore be based on more parameters than just the HV interval in BBB patients. A more tailored approach should be the basis of modern treatment regimens.

Regarding PVC ablation, we showed that the inferior axis, which was considered typical for PVCs from the outflow tract, must also be considered for PVCs arising from the left ventricular inflow tract (Chapter 8 ). In combination with positive concordance at the precordial leads of the ECG, such PVCs could be effectively ablated from the coronary venous system.

Finally, we described two different entities that lead to an important ECG spot diagnosis. In particular, we could show that PVCs from the moderator band are common for the short-coupled variant of torsade de pointes (Chapter 9). Mapping and ablation at the lateral free right ventricular wall was possible by different mapping systems. Left superior frontal axis, late precordial LBBB-like transistion and a coupling interval less than $300 \mathrm{~ms}$ offers the spot diagnosis of this life threatening arrhythmia in young people. 